\title{
Seasonal Variation of the Osumi River
}

\author{
Gentiana Shegani
}

Directorate of Public Health, Albania

Copyright $\mathrm{O} 2016$ by authors, all rights reserved. Authors agree that this article remains permanently open access under the terms of the Creative Commons Attribution License 4.0 International License

\begin{abstract}
A study of the Osumi River possesses great importance because of its strategic geographical position, and for the fact that high quality water can affect aquatic flora and fauna. Determinant factors that influence quality river water quality include climatic conditions, such as temperature variation, amount of rainfall and erosion of the soil. This investigation represents the seasonal variation of different physical, chemical and bacteriological parameters, consequently to estimate the pollution status of Osumi River depending on weather conditions during the dry and rainy season. This study was carried out for a period of two years from January 2012 to December 2013. Five sampling stations were established during this investigation. The collected samples were divided into two groups. Each group depended on the weather conditions during the study period: October 2012- February 2013, during cool-cold weather (the wet season); March 2012- September 2013, during warm-hot weather (the dry season). The maximum $\mathrm{pH}$ value 9.04 was observed as a result of the discharge of tannery wastewaters into river water of this area. COD (Chemical Oxygen Demand) values ranged from 7.97 to $51.63 \mathrm{mg} / \mathrm{L} \mathrm{O}_{2}$ during the dry season and from 13.4 to $171.37 \mathrm{mg} / \mathrm{L} \mathrm{O}_{2}$ during the wet season. Chloride levels ranged from 17.74 to $258.27 \mathrm{mg} / \mathrm{L}$ during the dry season and from 21.27 to 685.83 $\mathrm{mg} / \mathrm{L}$ during the wet season. TSS values exceeded many times the limit of the EU Directive- $50 \mathrm{mg} / \mathrm{L}$ for the quality of fresh waters for aquatic life. Seasonal values of physical, chemical and bacteriological parameters of Osumi River varied according to sampling sites depending on the quantity and activity of the source of pollution into the river water. Variation according to season did not adhered to any specific trends.
\end{abstract}

Keywords Bacteriological Parameter, Osumi River, Physic Chemical Parameter, Pollution, Seasonal Variation

\section{Introduction}

Water resources such as rivers, lakes and springs are of a great importance for the sustenance of all life. Water chemistry is responsible for many of the characteristics associated with the quality of rivers. Monitoring water resources will quantify water quality and identify impairments, in order to not only preserve natural areas, but to improve the quality of life as well, (Bellingham, 2009). An interdependent relationship exists between rivers and atmosphere. Variation of climate conditions can cause seasonal variation among all parameters of water systems; thereby inducing seasonal variation of water quality. A comprehensive study of the Osumi River is very important for several reasons, first of which being its strategic geographical position. The Osumi River passes through the city of Berat by dividing it into two parts. Quality performance of aquatic systems plays an important role in the city ecosystem. A quality aesthetic appearance of river water, not turbid, without bad smells, no eutrophication, positively affects urban development and tourism of the city of Berat, which is known for its numerous antique and museum attractions. 2) Another major reason to study the Osumi River is that a good water quality supports aquatic flora and fauna. The diversity of organisms that may survive in any body of water is limited to the fluctuating conditions prevailing within it, Alagoa et al. (2012). This is subject to the varying levels of the physical and chemical parameters of the river water such as temperature, $\mathrm{pH}$, Chemical Oxygen Demand (COD), total suspended solids, total dissolved solids, ammonium, nitrate, phosphate, chloride and bacteriological parameters such as coliform bacteria, Escherichia Coli and Streptococcus Faecalis. Different industrial effluents such as agricultural run-off and urban wastes end up as sewage in the river. Determining factors that influence river water quality include climate conditions, such as temperature variation, amount of rainfall and soil erosion, which appears to be a critical and prevalent phenomenon within Albanian aquatic systems. This investigation illustrates the seasonal variation of different physical, chemical and bacteriological parameters. These various parameters help to estimate the pollution status of the Osumi River depending on weather conditions during the dry and rainy seasons. In this area the summer temperature average is about $32^{\circ} \mathrm{C}$, humidity is low. Usually it is a mild winter, averaging about $7^{\circ} \mathrm{C} .95 \%$ of the annual precipitation falls in winter. This is the first study of its kind for the Osumi River. One of the objectives of this study was also to complete data sets related to the river from the author's previous study. 


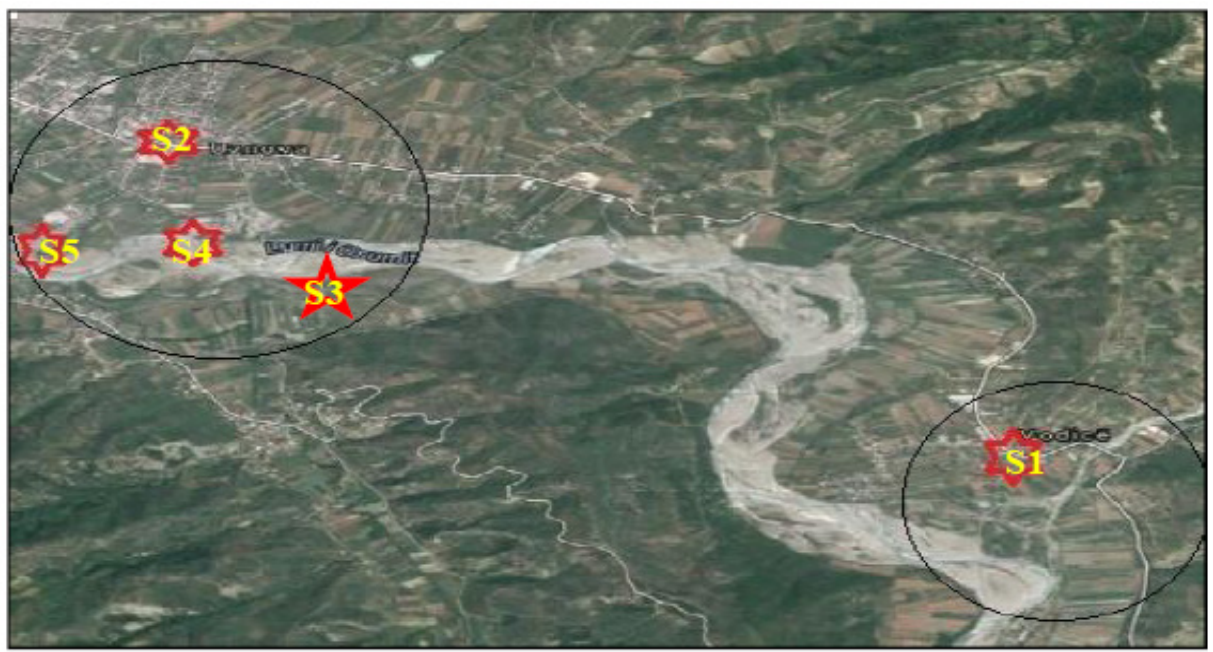

Figure 1. Map of the sampling water stations

\section{Materials and Methods}

This study was carried out for a period of two years from January 2012- December 2013 during 4 seasons (summer dry season, winter - rainy season, spring and autumn - mild seasons). Water samples were collected 3-4 times per month (from 9-11am), with grab sampling in $1000 \mathrm{~mL}$ polyethylene bottles. Five sampling stations were established during the investigation. Station 1 was the Vodica stream, located $5 \mathrm{~km}$ away from Berat. The stream was the confluence point with tannery effluents that were discharged in an irregular way into the Vodica brook; Station 2 was the confluence point with the tannery wastewaters that were regularly discharged into Osumi River; Station 3 was almost $150 \mathrm{~m}$ away from Station 2; Station 4 was roughly 500-600m from Station 3, it was located within an area, where private activities had an effect on it, such as a nearby car-wash. Station 5 was located at the Gorica Bridge, a very populated urban area, where urban waste and sewage are known to be discharged. The collected samples were divided into two groups, depending on the weather conditions during the study period: October 2012- February 2013, during cool-cold weather (the wet season); March 2012- September 2013, during warm-hot weather (the dry season).

The obtained data were subjected to descriptive statistical analysis using Excel and the Statistical Package for Social Sciences (SPSS), to determine the minimum, maximum, median, mean, standard deviation, coefficient of variation, and threshold. Each sample was analyzed for physical, chemical and bacteriological parameters by standard methods. pH was determined by a "Selecta" $\mathrm{pH}$-meter. Total alkalinity was determined with the standard method. COD was analyzed with the permanganate index. Ammonia ions were determined by use of the Nesslerization method. Chlorides were analyzed with the method of Argentometria. Nitrate ions and phosphates were determined with Test Kits 12, 6 dimethylphenol and ammonium molybdate, respectively. TSS and TDS were determined with filtration and the gravimetric method.

\section{Results}

Average values of physical, chemical and bacteriological parameters are presented in Table 1; A statistical summary of parameters, such as $\mathrm{pH}$ and Total Alkalinity are presented in Table 2; Seasonal statistics of $\mathrm{NH}_{4}{ }^{+}, \mathrm{NO}_{3}{ }^{-}, \mathrm{PO}_{4}{ }^{3-}$ values are presented in Table 3; Statistics of $\mathrm{Cl}^{-}, \mathrm{COD}$, and $\mathrm{SO}^{-2}$ values are presented in Table 4; Seasonal statistics of TSS; TDS and Fe values are presented in Table 5.

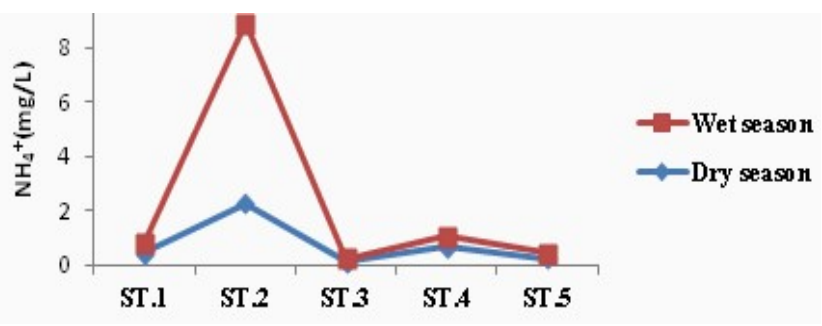

Figure 2. Seasonal variation of average $\mathrm{NH}_{4}{ }^{+}$values 2012-2013 
Table 1. Physical, chemical and microbiological parameters of the Osumi River during dry - wet season 2012- 2013

\begin{tabular}{|c|c|c|c|c|c|}
\hline Parameter & Station 1 & Station 2 & Station 3 & Station 4 & Station 5 \\
\hline Temp. ${ }^{\circ} \mathrm{C}$ & $26.03-15.75$ & $22.94-18.28$ & $2352-16.53$ & $23.29-16.18$ & $23.75-16.37$ \\
\hline $\begin{array}{l}\mathrm{pH} \\
\text { Total Alkalinity } \\
(\mathrm{mg} / \mathrm{L} \mathrm{CaCO} \text { ) }\end{array}$ & $\begin{array}{c}8.25-8.02 \\
83.88-79.1\end{array}$ & $\begin{array}{l}8.3-9.04 \\
82.16-224.85\end{array}$ & $\begin{array}{l}7.64-7.54 \\
63-60.75\end{array}$ & $\begin{array}{l}8.08-7.98 \\
70.95-69.78\end{array}$ & $\begin{array}{l}7.94-7.92 \\
68.17-71.8\end{array}$ \\
\hline \multicolumn{5}{|l|}{$(\mathrm{NH}+3$ (mgl) } & $0.21-0.205$ \\
\hline Nitrate (mgl) & $3.47-1.55$ & $11.9-23.14$ & $0.68-0.151$ & $2.39-2.206$ & $2.44-1.47$ \\
\hline $\begin{array}{l}\text { Phosphate (mg/L } \\
\text { Chloride (mg L) }\end{array}$ & L) $1.009-0.18$ & $\begin{array}{c}2.104-2.57 \\
258.27-685.83\end{array}$ & $\begin{array}{l}0.068-0.036 \\
17.74-21.27\end{array}$ & $\begin{array}{l}0.798-0.59 \\
33.8-40.2\end{array}$ & $\begin{array}{l}0.4-0.31 \\
32.98-37.71\end{array}$ \\
\hline $\begin{array}{l}\text { COD man }(m g L / \\
\text { Sulfate (mg/) }\end{array}$ & $\begin{array}{c}\left.\mathrm{O}_{2}\right) 40.73-20.55 \\
53.15-41.81\end{array}$ & $\begin{array}{c}51.63-171.37 \\
112.48-303.71\end{array}$ & $\begin{array}{l}7.97-13.4 \\
9.49-7.28\end{array}$ & $\begin{array}{l}21.29-21.67 \\
38.61-22.15\end{array}$ & $\begin{array}{l}20.62-18.97 \\
30.8-27.02\end{array}$ \\
\hline $\begin{array}{l}\operatorname{TSS}(\mathrm{mg} / \mathrm{L}) \\
\operatorname{IDS}(\mathrm{mg} / \mathrm{L})\end{array}$ & $\begin{array}{c}2523-165.9 \\
733.64-276.6\end{array}$ & $\begin{array}{c}2546.56-1019.57 \\
902.9-1643.43\end{array}$ & $\begin{array}{c}61334-1594.17 \\
160.98-99.63\end{array}$ & $\begin{array}{l}590.54-821.46 \\
249.42-245.66\end{array}$ & $\begin{array}{l}675.56-273.05 \\
175.12-215.07\end{array}$ \\
\hline $\mathrm{Fe}^{2+2+}(\mathrm{mg} / \mathrm{L})$ & $0.029-0.003$ & $0.051-0.208$ & $0.0035-0.003$ & $0.057-0.049$ & $0.113-0.12$ \\
\hline $\begin{array}{l}\text { (E.Coli) } \\
\text { (St. Faecalis) } 71\end{array}$ & $\begin{array}{l}02.35-1095.78 \\
11.89-632.72\end{array}$ & $\begin{array}{c}1436.25-1378.66 \\
761.33-810.57\end{array}$ & $\begin{array}{c}836.4-939.16 \\
378.94-479.08\end{array}$ & $\begin{array}{c}1449.54-1458.78 \\
789.1-778.78\end{array}$ & $\begin{array}{c}1291.37-1483.4 \\
683.77-815.68\end{array}$ \\
\hline $\mathrm{Cr}(\mathrm{VD})(\mathrm{mg} / \mathrm{L})$ & $0.039-0.004$ & $0.099-0.105$ & & & \\
\hline $\mathrm{H}_{2} \mathrm{~S}(\mathrm{mg} / \mathrm{L})$ & $50.21-10.39$ & $146.8-203.51$ & & & \\
\hline
\end{tabular}

Table 2. Summary of basic statistics of $\mathrm{pH}$ and Total Alkalinity during dry -wet season 2012-2013

\begin{tabular}{|c|c|c|c|c|c|}
\hline \multicolumn{6}{|l|}{ Statistical } \\
\hline Parameter "C & Station 1 & Station 2 & Station 3 & S tation 4 & S tation 5 \\
\hline $\begin{array}{l}\text { Minimum } \\
\text { Maximum }\end{array}$ & $\begin{array}{l}7.8-7.6 ; 61-69 \\
9-8.8 ; 145-89\end{array}$ & $\begin{array}{l}7.8-7.8 ; 65-67 \\
8.8-10.5 ; 140- \\
460\end{array}$ & $\begin{array}{l}7.2-7.1 ; 54-55 \\
8-7.8 ; 72-67\end{array}$ & $\begin{array}{l}7-4-7.4 ; 58-52 \\
8.8-8.5 ; 80-78\end{array}$ & $\begin{array}{l}7.1-7.4 ; 57-57 \\
8.5-8.5 ; 80-81\end{array}$ \\
\hline Average & $\begin{array}{l}8.25-8.02 ; 83.88- \\
79.1\end{array}$ & $\begin{array}{l}8.3-9.04 ; 82.16- \\
224.85\end{array}$ & $\begin{array}{l}7.64-7.54 ; 63- \\
60.75\end{array}$ & $\begin{array}{l}8.082- \\
7.98 ; 70.95- \\
69.78\end{array}$ & $\begin{array}{l}7.94-7.92 ; 68.17 \\
71.8\end{array}$ \\
\hline $\begin{array}{l}\text { Median } \\
\text { Standard Dev. }\end{array}$ & $\begin{array}{l}8.25-8 ; 79-79.5 ; \\
0.37- \\
0.357 ; 21.72- \\
5.64 ;\end{array}$ & $\begin{array}{l}8.35-9 ; 78-150 ; \\
0.388- \\
0.97 ; 20.51- \\
168.39\end{array}$ & $\begin{array}{l}7.6-7.65 ; 62-60 \\
0.22-0.25 ; 5.47- \\
3.36\end{array}$ & $\begin{array}{l}8-8 ; 72-70 ; \\
0.32-0.22 ; 6.41- \\
6.08 ;\end{array}$ & $\begin{array}{l}7.9-8 ; 69-73 ; \\
0.326-0.24 ; 7.59- \\
6.05 ;\end{array}$ \\
\hline Coeff. of Variac. & $\begin{array}{l}0.044 \\
0.044 ; 0.26 \\
0.071\end{array}$ & $\begin{array}{l}0.046-0.1 ; 0.25- \\
0.75\end{array}$ & $\begin{array}{l}0.028- \\
0.033 ; 0.087- \\
0.055 ;\end{array}$ & $\begin{array}{l}3.95-0.027 ; 0.09- \\
0.087 ;\end{array}$ & $\begin{array}{l}0.04-0.03 ; 0.11- \\
0.084\end{array}$ \\
\hline Threshold & $\begin{array}{l}8.99- \\
8.73 ; 127.32- \\
90.38\end{array}$ & $\begin{array}{l}9.07- \\
10.98 ; 123.2- \\
561.63 ;\end{array}$ & $\begin{array}{l}8.08-8.04 ; 73.94- \\
67.47\end{array}$ & $\begin{array}{l}8.72-8.42 ; 83.77- \\
81.94 ;\end{array}$ & $\begin{array}{l}8.59-8.4 ; 83.35- \\
83.9\end{array}$ \\
\hline
\end{tabular}

Table 3. Summary of basic statistics of $\mathrm{NH}_{4}{ }^{+}, \mathrm{NO}_{3}{ }^{-}$and $\mathrm{PO}^{3-}$ values during dry-wet season 2012-2013

\begin{tabular}{|c|c|c|c|c|c|}
\hline \multicolumn{6}{|l|}{ Statistical } \\
\hline \multicolumn{6}{|l|}{ Parameter ${ }^{\circ} \mathrm{C}$} \\
\hline Minimum & $\begin{array}{l}0.1-0.05 ; \quad 0.5- \\
0.01 ; 0.05-0\end{array}$ & $\begin{array}{l}0.16-0.5 ; 1- \\
2 ; 0.05-1.5\end{array}$ & $\begin{array}{l}0.02-0.05 ; 0.01- \\
0,0-0\end{array}$ & $\begin{array}{l}0.1-0.15 ; 0.1- \\
0.05 ; 0.1-0.01\end{array}$ & $\begin{array}{l}0.05-0.05 ; 0.1- \\
0 ; 0.05-0:\end{array}$ \\
\hline Maximum & $\begin{array}{l}2-3 ; 10-10 \\
3-2\end{array}$ & $15-12 ; 30-50 ; 7-3$ & $\begin{array}{l}0.3-0.2 ; 3-1 ; 0.2- \\
0.2\end{array}$ & $3-2 ; 5-10 ; 2-1.5$ & $\begin{array}{l}0.5-0.5 ; 5-3 ; 1- \\
1.5 ;\end{array}$ \\
\hline Average & $\begin{array}{l}0.438-0.35 ; 3.47- \\
1.55 ; 1.009-0.18\end{array}$ & $\begin{array}{l}2.26-6.64 ; 11.9- \\
23.14 ; 2.104- \\
2.57 ;\end{array}$ & $\begin{array}{l}0.1-0.104 ; 0.68- \\
0.151 ; 0.068- \\
0.036\end{array}$ & $\begin{array}{l}0.665-0.38 ; 2.39- \\
2.206 ; 0.798- \\
0.59\end{array}$ & $\begin{array}{l}0.21-0.205 ; 2.44 \\
1.47 ; 0.4-0.31\end{array}$ \\
\hline $\begin{array}{l}\text { Median } \\
\text { Standard Dev. }\end{array}$ & $\begin{array}{l}0.25-0.1 ; 2- \\
0.05 ; 1.35-0.01 \\
0.346-0.7 ; 2.85-\end{array}$ & $\begin{array}{l}0.95-9 ; 10- \\
15 ; 1.6-2 ; \\
4.12-4.64 ; 10.17-\end{array}$ & $\begin{array}{l}0.1-0.1 ; 0.5- \\
0.05 ; 0.05-0.01 ; \\
0.047-\end{array}$ & $\begin{array}{l}0.3-0.2 ; 3-2 ; 0.8- \\
0.5 ; \\
0.76-0.423 ; 1.29-\end{array}$ & $\begin{array}{l}0.2-0.2 ; 2.5- \\
2: 0.3-0.2 ; \\
0.11-0.12 ; 1.31-\end{array}$ \\
\hline & 3.22;0.97-0.47; & $18.95 ; 2.12-1.17$ & $\begin{array}{l}0.045 ; 0.653- \\
0.299 ; 0.053- \\
0.06 ;\end{array}$ & $2.12 ; 0.55-0.45$ & $1.2 ; 0.28-0.36$ \\
\hline $\begin{array}{l}\text { Coeff. of Variac. } \\
\text { Threshold }\end{array}$ & $\begin{array}{l}0.79-2.01 ; 0.82- \\
2.07 ; 0,96-2.65 \\
1.13-0.48: 9.17\end{array}$ & $\begin{array}{l}1.82-0.69 ; 0.85- \\
0.82 ; 1.01-0.45 \\
10.5-\end{array}$ & $\begin{array}{l}0.47-0.43 ; 0.96 \\
1.98 ; 0.78-1.66 \\
0.19-0.19 ; 1.98\end{array}$ & $\begin{array}{l}1.14-1.11 ; 0.54 \\
0.96 ; 0.68-0.76 \\
2.18-1.22 ; 4.97\end{array}$ & $\begin{array}{l}0.52-0.58 ; 0.53- \\
0.81 ; 0.7-1.16 \\
0.43-0.44 ; 5.06\end{array}$ \\
\hline & $7.99,2.94-1.12$ & $\begin{array}{l}15.92 ; 32.25- \\
61.04 ; 6.34-4.91\end{array}$ & $0.75 ; 0.17-0.156$ & $6.45 ; 1.89-1.49$ & $3.87 ; 0.96-1.03$ \\
\hline
\end{tabular}




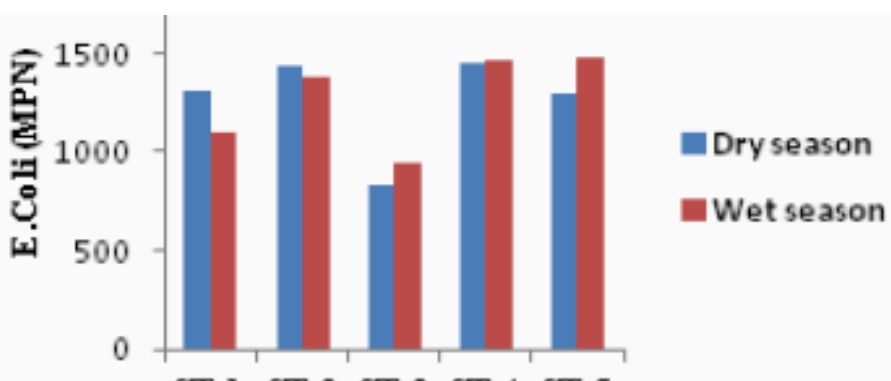

ST 1 ST 2 ST 3 ST 4 ST 5

Figure 3. Seasonal variation of average E. Coli (MPN) values 2012-2013

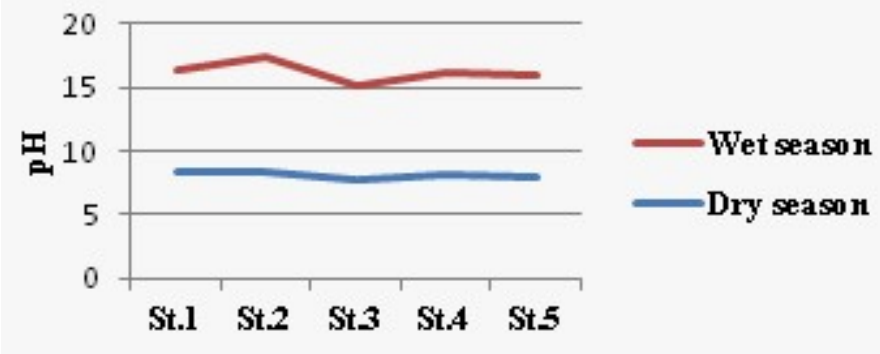

Figure 4. Seasonal variation of average $\mathrm{pH}$ values 2012-2013

Table 4. Summary of basic statistics of $\mathrm{Cl}^{-}, \mathrm{COD}$, and $\mathrm{SO}^{-2}$ values during dry-wet season 2012- 2013

\begin{tabular}{|c|c|c|c|c|c|}
\hline \multicolumn{6}{|l|}{ Statistical } \\
\hline Parameter ${ }^{\circ} \mathrm{C}$ & Station 1 & Station 2 & Station 3 & Station 4 & Station 5 \\
\hline Minimum & $\begin{array}{l}21.27-14.2 ; 48- \\
8 ; 2.86-2.88 ;\end{array}$ & $\begin{array}{l}17.72-141.8 ; 3.2- \\
25.6 ; 12.34- \\
27.57\end{array}$ & $\begin{array}{l}4.18-10.63 ; 1.6- \\
3.2 ; 1.23-0.82\end{array}$ & $\begin{array}{l}17.72-21.27 ; 6.4 \\
80 ; 6.95-1.54\end{array}$ & $\begin{array}{l}8-14.2 ; 4.8- \\
8 ; 4.11-1.64\end{array}$ \\
\hline Maximum & $\begin{array}{l}1169.9- \\
253.2 ; 74.4- \\
56.4 ; 182-198.75 ;\end{array}$ & $\begin{array}{l}1949.7- \\
1109.85 ; 130- \\
286 ; 288.87- \\
1416.38\end{array}$ & $\begin{array}{l}35.45-31.9,44 \\
33.0 ; 41.0-14.9\end{array}$ & $\begin{array}{l}67.45-85.7 ; 64- \\
7.2 ; 180.81- \\
43.73 ;\end{array}$ & $\begin{array}{l}74.44-99.26 ; 68- \\
50 ; 78.09-139 ;\end{array}$ \\
\hline Averago & $\begin{array}{l}250.83- \\
48.14 ; 40.73- \\
20.55: 53.15- \\
41.81 ;\end{array}$ & $\begin{array}{l}258.27- \\
685.83 ; 51.63- \\
171.37 ; 112.48- \\
303.71 ;\end{array}$ & $\begin{array}{l}17.74 \\
21.27 ; 7.97- \\
13.49 .49-7.28\end{array}$ & $\begin{array}{l}33.8-40.2 ; 21.20- \\
21.67 ; 38.61- \\
22.15 ;\end{array}$ & $\begin{array}{l}32.98- \\
37.71 ; 20.62- \\
18.97 ; 30.8- \\
27.02\end{array}$ \\
\hline Median & $\begin{array}{l}115.25- \\
24.83 ; 67- \\
15.2 ; 61.48- \\
23.65 ;\end{array}$ & $\begin{array}{l}63.81- \\
815.35 ; 60.2- \\
136 ; 55.59- \\
154.72 ;\end{array}$ & $\begin{array}{l}14.18-21.27,4.8- \\
10.8 ; 6.84-6.61\end{array}$ & $\begin{array}{l}35.45- \\
35.45 ; 14.4 \\
18.8 ; 28.8-24.8\end{array}$ & $\begin{array}{l}31.9-38.5 ; 10.4 \\
16 ; 25.36-23.26\end{array}$ \\
\hline Standard Dev. & $\begin{array}{l}394.12- \\
64.06 ; 29.5- \\
15.34 ; 38.65- \\
56.07 ;\end{array}$ & $\begin{array}{l}541.4- \\
356.72 ; 37.37- \\
105.81 ; 104.67- \\
493.63 ;\end{array}$ & $\begin{array}{l}7.05-6.93 ; 8.43- \\
10.33 ; 8.39- \\
4.256\end{array}$ & $\begin{array}{l}14.57- \\
17.29,17.32- \\
15 ; 32.25-12.96\end{array}$ & $\begin{array}{l}16.94- \\
21.44 ; 18.42- \\
10.97 ; 17.23- \\
26.34 ;\end{array}$ \\
\hline $\begin{array}{l}\text { Coeff. of Variac. } \\
\text { Threshold }\end{array}$ & $\begin{array}{l}1.57-1.33 ; 0.72- \\
0.74 ; 0.73-1.34 ; \\
1030.1- \\
176.26 ; 99.73- \\
51.23 ; 130.45- \\
153.95 ;\end{array}$ & $\begin{array}{l}2.1-0.52 ; 0.72- \\
0.62 ; 0.93-1.62 \\
1341.1- \\
1399.3 ; 126.4- \\
382.9 ; 321.8- \\
1290.9\end{array}$ & $\begin{array}{l}0.39-0.32 ; 1.05- \\
0.77 ; 0.88-0.58 \\
31.84 \\
35.142,24.83- \\
34.06,26.27- \\
15.79\end{array}$ & $\begin{array}{l}0.43-0.43 ; 0.81- \\
0.69 ; 0.83-0.58 \\
62.04- \\
74.78 ; 55.93- \\
51.67 ; 103.11- \\
48.07 ;\end{array}$ & $\begin{array}{l}0.51-0.57 ; 0.89- \\
0.58 ; 0.56-0.97 \\
66.86- \\
80.59 ; 57.46- \\
40.91 ; 65.26- \\
79.7 ;\end{array}$ \\
\hline
\end{tabular}

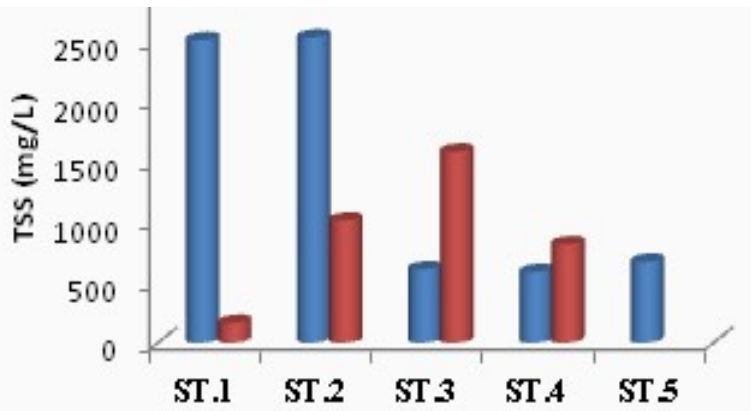

Dry season

Wet season

Figure 5. Seasonal variation of average TSS values 2012-2013 
Table 5. Summary of basic statistics of TSS; TDS and Fe during dry -wet season 2012-2013

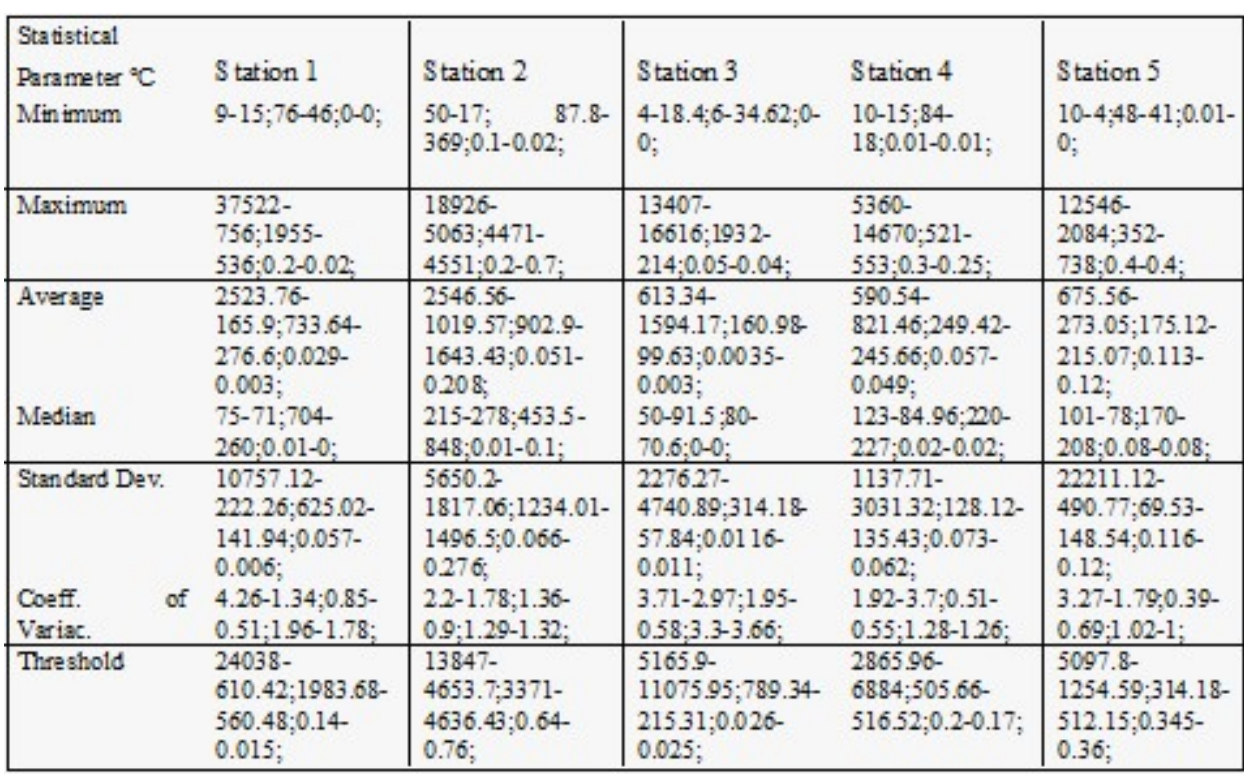

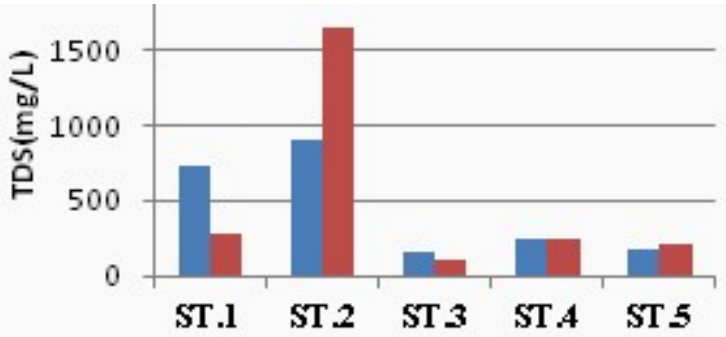

\section{Dry season \\ Wet season}

Figure 6. Seasonal variation of average TDS values 2012-2013

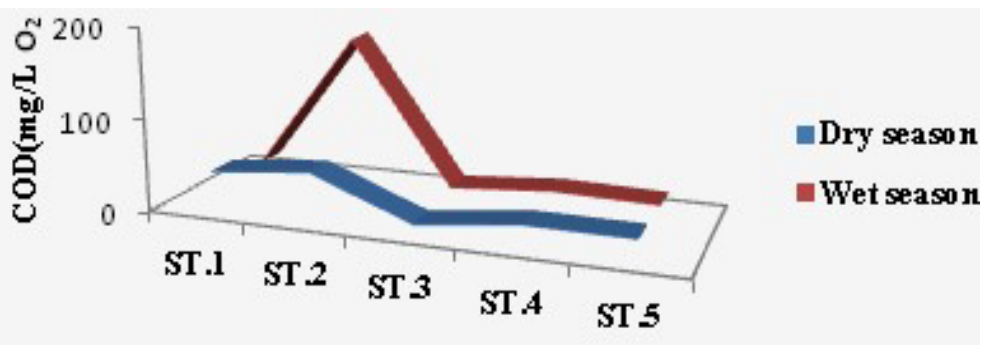

Figure 7. Seasonal variation of average $\mathrm{COD}_{(\mathrm{IMn})}$ values 2012-2013

The surface water temperature ranged from $16^{\circ} \mathrm{C}$ to $30^{\circ} \mathrm{C}$ during the dry season and from 9.3 to $25^{\circ} \mathrm{C}$ during the wet season. The temperature of the water reflected changes corresponding to sampling seasons and was influenced by the intensity of solar radiation, (Tukura, 2012). The $\mathrm{pH}$ of the aquatic systems is an important indicator of water quality and the extent of pollution. Unpolluted rivers normally show near neutral or slightly alkaline $\mathrm{pH}$, (Tukura, 2012). The maximum $\mathrm{pH}$ value of 9.04 was observed at St. 2 as a result of the tannery wastewaters discharged into the river in this area. The $\mathrm{pH}$ values in other stations during dry and wet seasons are shown in Fig.4, which were within norms of the EU Directive "Quality of fresh waters supporting fish life", (Miho et al., 2005). Nitrates are normally the common form of combined inorganic \& organic nitrogen in lakes and streams, (Pawale, 2012). The maximum value of nitrate
$(23.14 \mathrm{mg} / \mathrm{L})$ was found during the rainy season at St.2 as a result of industrial wastewaters. Conversely, the minimum value $(0.68 \mathrm{mg} / \mathrm{L})$ was found during the dry season at St.3. In five stations, nitrate values during the dry and wet seasons were within permissible limits set by the USEPA, (Ugwu, 2012). Phosphate values ranged from 0.068 to $2.104 \mathrm{mg} / \mathrm{L}$ during the dry season and from 0.036 to $2.57 \mathrm{mg} / \mathrm{L}$ during the wet season. The highest concentrations of phosphates during both seasons were found at St. 2, - 2.104 to $2.57 \mathrm{mg} / \mathrm{L}$. This may be due to the high amount of phosphates in the tannery wastewaters carried that were discharged into this area of the river. At St.3 the phosphate values were within the limit of $0.04 \mathrm{mg} / \mathrm{L}$ set by the EU Directive (Miho et al., 2005). During the dry and wet season, other stations had phosphates values that were above the prescribed limit. This was probably due to different industrial activities and the 
discharge of agricultural runoff into the river at these locations. In the present study ammonia ions ranged from 0.1 to $2.26 \mathrm{mg} / \mathrm{L}$ during the dry season and from 0.104 to 6.64 $\mathrm{mg} / \mathrm{L}$ during the wet season. The higher concentrations of ammonia ions (2.26-6.64 mg/L) were observed at St.2 during both seasons. This was likely caused by tannery wastewaters with high organic loads being discharged into the river. In other stations the manmade sources of ammonia included fertilizer runoff and sewage releases- their values were within the limits set forth by the EU Directive for fisheries and aquatic life, (Miho et al., 2005). COD (Chemical Oxygen Demand) values ranged from 7.97 to $51.63 \mathrm{mg} / \mathrm{L} \mathrm{O}$ during the dry season and from 13.4 to $171.37 \mathrm{mg} / \mathrm{L} \mathrm{O}$ during the wet season. The higher quantity of COD was observed at St.2 from $51.63 \mathrm{mg} / \mathrm{L} \mathrm{O}_{2}$ during the dry season to $171.37 \mathrm{mg} / \mathrm{L} \mathrm{O} \mathrm{O}_{2}$ during the wet season as a result of the discharge of industrial effluents. At St.3 COD values ranged from 7.97-13.4 mg/L $\mathrm{O}_{2}$ for both seasons. They were within norms of NIVA, (Miho et al., 2005). On the other hand, COD values in other stations were above the prescribed limit. Chloride levels ranged from 17.74 to $258.27 \mathrm{mg} / \mathrm{L}$ during the dry season and from 21.27 to $685.83 \mathrm{mg} / \mathrm{L}$ during the wet season. Higher concentrations of chloride were observed at St.2 from 258.27 to $685.83 \mathrm{mg} / \mathrm{L}$. The existence of high amounts of chloride here was due to the discharge of tannery effluents into the river. For this same reason chloride levels at St.1, ranged from 48.14 during the wet season to 250.83 $\mathrm{mg} / \mathrm{L}$ during the dry season. This may be as a result of the irregular discharge of tannery wastes in this area. An excess of chloride beyond desirable limits in river water is considered as index of water pollution, (Kumar, 2012). The concentration of chloride at four stations was within the prescribed limit of the USEPA-250mg/L, (Ugwu, 2012), with the exception of the St.2. Water sulfate varied from 9.49 to $112.48 \mathrm{mg} / \mathrm{L}$ during the dry season and from 7.28 to $303.71 \mathrm{mg} / \mathrm{L}$ in the rainy season. The maximum sulfate values were recorded at St.2 from 112.48 in the dry season to $303.71 \mathrm{mg} / \mathrm{L}$ in the wet season. An increase in water sulfate levels may be attributed to the influx of tannery wastewaters with high amount of sulfates in this area of the Osumi River. In other stations, the sulfates may exist because of fertilizers and urban runoff and were within the limit set by the USEPA, 250mg/L, (Ugwu, 2012). TSS (Total Suspended Solids) ranged from 590.54 to $2546.56 \mathrm{mg} / \mathrm{L}$ during the dry season and from 165.9 to $1594.17 \mathrm{mg} / \mathrm{L}$ during the wet season. The higher concentrations of TSS were observed at St.2 from 1019.57 to $2546.56 \mathrm{mg} / \mathrm{L}$ during both seasons. However, TSS values in other stations exceeded many times the limit of EU Directive $-50 \mathrm{mg} / \mathrm{L}$, for the quality of fresh waters for fish life, (Miho et al., 2005). The sources of TSS can include erosion, industrial discharges, microorganisms, and eutrophication, (Bellingham, 2012). Erosion of soil remains a great problem for all rivers in Albania. TDS (Total Dissolved Solids) indicates the total amount of inorganic chemicals which becomes higher with the increasing pollution, (Kumar, 2012). In this study, TDS values ranged from 160.98 to $902.9 \mathrm{mg} / \mathrm{L}$ during the dry season and from 99.63 to $1643.3 \mathrm{mg} / \mathrm{L}$ during the wet season. The higher TDS values were observed at St.2 from 902.9 to $1643.3 \mathrm{mg} / \mathrm{L}$ for both seasons. This is the result of high amounts of chemicals which were dissolved in tannery wastewaters discharged directly into the river. TDS concentrations were above the limit set by the USEPA-500mg/L, at St .1 and St. 2 as a result of the discharge of industrial wastes. In other stations, however, TDS values were within the norm of the limits set by the USEPA, (Ugwu, 2012). Iron ions ranged from 0.0035 to $0.113 \mathrm{mg} / \mathrm{L}$ during the dry season and from 0.003 to 0.12 $\mathrm{mg} / \mathrm{L}$ in the rainy season. The highest concentration of iron was found at St.2 from $0.051-0.208 \mathrm{mg} / \mathrm{L}$ for both of the seasons as a result of the industrial wastes with iron in their content, as well as at St. 5 from $0.113-0.12 \mathrm{mg} / \mathrm{L}$ as a result of the influx of sewage and urban runoff that were discharged into the river water. The iron values were above the limit set by NIVA, $0.05 \mathrm{mg} / \mathrm{L}$, (Miho et al., 2005) at St. 2 and St.5. However, other stations had iron values that were within the prescribed limit. Bacteriological parameters such as E.Coli and St.Faecalis showed evidence of sewage and industrial effluent contamination, (Kanu et al., 2011). For E.Coli, they ranged from 836.4 to 1449.54 and St.Faecalis from 378.94 to 789during the dry season. E.Coli ranged from 939.16 to 1483 and St.Faecalis from 479.08 to 815.68 during the wet season. Higher values of E.Coli and St.Faecalis were at St.2, from 836.4-1449.54 for E.Coli and from 939.16-1483.4 for St.Faecalis, but and in the other stations their values were above the limit of NIVA, (Miho et al., 2005). Chromium and $\mathrm{H}_{2} \mathrm{~S}$ values were found in the river water at St. 1 and St.2 where the tannery wastewaters were discharged into the river. Chromium (VI) ranged from 0.039 to $0.099 \mathrm{mg} / \mathrm{L}$ during the dry season and from $0.0040 .105 \mathrm{mg} / \mathrm{L}$ in the rainy season. $\mathrm{H}_{2} \mathrm{~S}$ ranged from 50.21 to $146.8 \mathrm{mg} / \mathrm{L}$ during the dry season and from 10.39 to $203.51 \mathrm{mg} / \mathrm{L}$ during the rainy season depending on the source of pollution.

\section{Conclusions}

Seasonal values of physical, chemical and bacteriological parameters of the Osumi River varied according to sampling sites depending on the quantity and activity of the source of pollution released into the river. Variation according to season did not induce any specific trends. All seasonal parameters at St.2 were above the limits set by USEPA, (Ugwu, 2012) and EU Directive for fresh waters, (Miho et al., 2005). This is most likely due to the stronger environmental impact of tannery wastewaters that were discharged without any treatment into the river water. In four sampling sites, seasonal parameters such as $\mathrm{pH}$, Total Alkalinity, ammonia ions, chloride, sulfate, iron ions, nitrate, phosphate and TDS were within the norms set by the above prescribed limits, during both the dry and wet seasons, with exception of the higher values of COD and TSS during both seasons. Seasonal values of the bacteriological parameters such as 
E.Coli and St. Faecalis were above the limit of NIVA, (Miho et al., 2005) in all stations during the dry and rainy seasons.

\section{REFERENCES}

[1] Alagoa KJ, Aleleye-Wokoma, IP, (2012) Human Induced Variations of Selected Physicochemical Parameters of Taylor Creek in the Niger Delta, Bayelsa State, Nigeria, J. Resources and Environ., 2(2), 45-50.

[2] Bellingham K, (2009) Physicochemical Parameters of Natural Waters, http://www.stevenswater.com/articles/waterparamet ers.aspx

[3] Etesin U, Udoinyang E, Harry T, (2013) Seasonal Variation of Physicochemical Parameters of Water and Sediments from Iko River, Nigeria, J. Environ. \& Earth Sci., 3(8), 96-104.

[4] Gangwar R. K, Khare P, Singh J, Singh A.P, (2012) Assessment of physic-chemical properties of water: River Ramganga at Bareilly, U.P., J. Chem. \& Pharmaceutical Res., 4(9), 4231-4234.

[5] Hebert Paul D. N, (2008) Chemical properties of rivers, file://F:/ Chemical properties of rivers.htm

[6] American Public Health Association/ American Water/ Water Environment Federation/WPCF

[7] Kanu, Ijeoma, Achi O.K, (2011) Industrial Effluents and their Impact on Water Quality of Receiving Rivers in Nigeria, $J$. Appl. Tech.n Environ. Sanitation, 1(1), 75-86.

[8] Kumar P.M, Prabhahar C, (2012) Physico-Chemical Parameters of River Water; A Review, International Journal of Pharmaceutical \& Biological Archives, 3(6), 1304-1312.

[9] Miho A, Çullaj A, Hasko A, Lazo P, Kupe L, Bachofen R, Brandl H, Schanz F, Baraj B, (2005) Environmental State of Some Rivers of Albanian Adriatic Lowland, Chapter II, (34-37), Chapter V , (103-121), (in Albanian).

[10] Pawale R. G, Lokhande M.V, (2012) Studies on Physicochemical Parameters of Dhanora Reservoir in Nanded District, Maharastra (India), 2, 76-78.

[11] Standard Methods for the Examination of Water and Wastewater, (1985), 16th edn, 20th edn, Washington DC, USA.

[12] S SH EN ISO 8467, (2000) Water quality. Determination of permanganate index.

[13] S SH EN ISO 9963-1, (1999) Water quality. Determination of total alkalinity, Potenciometric and titration method

[14] Tidame S. K, Shinde S. S, (2012) Studies on seasonal variations in physic-chemical parameters of the Temple pond Nashik District (M.S.), India, Int.l Multidis. Res. J., 2, 29-32.

[15] Thirupathaiah M, Samatha Ch, Sammaiah Ch,(2012) Analysis of water quality using physic-chemical parameters in lower manair reservoir of Karimnagar district, Andhra Pradesh, Int. J. Environ. Sciences, 3, 172-177.

[16] Tukura B.W, Gimba C.E, Ndukwe I.G, Kim B.C, (2012) Physicochemical characteristics of Water and Sediment in Mada River, Nasarawa State, Nigeria, Int. J. Environ. \& Bioenergy, 1(3).

[17] Ugwu A.I, Wakawa R.J, (2012) A study of seasonal physicochemical parameters in River Usma,

[18] American Journal of Environmental Science,8(5), 569-576. http://www.thescipub.com/ajes.toc 